\title{
Near zero mortality in juvenile Pinus hartwegii Lindl. after a prescribed burn and comparison with mortality after a wildfire
}

\author{
Ramón Hernández-Correa ${ }^{(1-3)}$, \\ Dante Arturo Rodríguez-Trejo ${ }^{(1)}$, \\ Arturo Cruz-Reyes ${ }^{(2)}$
}

\begin{abstract}
Fire is considered a relevant ecological factor, however, human alterations of fire regime facilitate more destructive wildfires. The aims of this work were to model probability of tree mortality and to identify the factors associated with leader shoot growth in a prescribed burn area and in a nearby wildfire area in a juvenile Pinus hartwegii Lindl. stand in central Mexico. A prescribed burn was carried out in 10-ha stand in March 2012, and compared with a close area affected by a wildfire occurred one week later, as well as with a nearby unburned area taken as control. A logistic model was used to estimate the probability of mortality, and a linear regression model was employed to investigate factors related to leader shoot growth. No tree mortality was recorded in the unburned control. In contrast, mortality was $6 \%$ in the prescribed burn and $66.9 \%$ in the wildfire area. The probability of mortality was influenced by stem char height (positively, $p<0.0001$ ), tree height (negatively, $p=0.0443$ ), and diameter at breast height (negatively, $\mathrm{p}<0.0001$ ). The variables that had more influence on leader shoot growth were stem char height (negatively, $\mathrm{p}<0.0001$ ) and tree height (positively, $\mathrm{p}<0.0001$ ). This work supports evidence of the feasibility of using low intensity prescribed burns in this ecosystem with minimum effects on young tree mortality.
\end{abstract}

Keywords: Fire Adaptations, Fire Ecology, Integral Fire Management, Prescribed Burning, Probability of Mortality, Logistic Regression, Pinus hartwegii

epicormic and basal resprouting, grass stage, serotinous cones, and fast initial growth (Rodríguez-Trejo \& Fulé 2003, Rodríguez-Trejo 2014). Pinus hartwegii Lindl. is one of the Mexican pine species with more fire adaptations, showing all but the last two. Such adaptations to fire have been identified for pines of the USA (Agee 1993, Whelan 1997) and Europe (Fernandes et al. 2008). Fire increases understory diversity and richness in this type of forest (Martínez-Hernández \& Rodríguez-Trejo 2008). This effect lasts no less than three years (Espinoza-Martínez et al. 2008). In this case, the higher the solar radiation (because of a reduction of tree canopy cover), the higher the presence of grasses (IslasMadrid et al. 2013). Fire also reduces fuel load and fire danger and maintains these $\square$ (1) División de Ciencias Forestales, Universidad Autónoma Chapingo, Chapingo, Edo. de Méx., km. 38.5 carretera México-Texcoco, C.P. 56230 (México); (2) Comisión Nacional Forestal, Puerta Calle Progreso 114, Santa Catarina, Del. Coyoacán, C.P. 04100, Ciudad de México (México); (3) Deceased

@ Dante Arturo Rodríguez-Trejo (dantearturo@yahoo.com)

Received: Feb 13, 2018 - Accepted: May 12, 2019

Citation: Hernández-Correa R, Rodríguez-Trejo DA, Cruz-Reyes A (2019). Near zero mortality in juvenile Pinus hartwegii Lindl. after a prescribed burn and comparison with mortality after a wildfire. iForest 12: 397-402. - doi: 10.3832/ifor2760-012 [online 2019-07-31]

Communicated by: Nicola Puletti forest habitats. Low crown scorch $(<30 \%)$ benefits secondary and primary growth for one to two years after the fire when precipitation is not limiting (González-Rosales \& Rodríguez-Trejo 2004, Vera-Vilchis \& Rodríguez-Trejo 2007). The probability of mortality for this species one year after fire is higher when the burn occurs in May, as a heading fire (more intense and more severe fire), on a dense stand (the fuel bed is mostly needle litter, whose combustion transmits more heat to the surface roots) with small dbh trees (with thinner bark), than when this occurs in March, as a backing fire (less intense and less severe fire), in open stands (the fuel bed is mostly grasses; when it burns most heat is transmitted to crowns) with large dbh trees and thicker bark (Rodríguez-Trejo et al. 2007).

In Mexico, pine forests extend over $5,238,861$ ha and this area increases to $16,176,825$ ha when the vast pine-oak associations are included (SEMARNAP/ UACH 1999). P. hartwegii is found in 17 states in Mexico, as well as in Guatemala and Honduras. Frequently, it grows in pure stands at altitudes between 3000 and $3700 \mathrm{~m}$ a.s.l. and as high as $4300 \mathrm{~m}$ where it forms the timber line (Perry 1991, Farjon et al. 1997). This is the pine species reaching the highest altitude worldwide and is thus relevant for global warming issues.

From 1998 to 2015, an average of 8198 recorded wildfires affected a mean surface area of 294,266 ha per year in Mexico. The main causes of wildfires in the country are 
agricultural activities and goat, sheep and cattle raising activities (36\%), followed by campfires (13\%) and smokers (12\%). Officially only $2 \%$ of wildfires are caused by lightning (CONAFOR 2012a). However, 17\% of fires have unknown causes, and some of them may be due to natural causes such as lightning. The agricultural and ranching group of wildfire causes is related to livelihood and poverty of the people living in rural areas.

Mexico is looking for what Myers (2005) called "integrated fire management", i.e., the optimal combination of ecological and silvicultural use of fire with its rural communitary use, modern fire prevention and firefighting (Rodríguez-Trejo 2000). A key tool for this type of fire management is prescribed burning (Scott et al. 2014). However, in order to apply such a tool, one of the several challenges is to understand the effects of fire on ecosystems. Most Mexican pines resist fire (Rodríguez-Trejo \& Fulé 2003), but one concern is the survival and growth of juvenile trees ( $<5 \mathrm{~m}$ height). A severe fire will kill pines smaller than $5 \mathrm{~m}$, unless they have the ability to resprout.

Logistic regression is a useful approach to investigate the effects of fire on probability of tree mortality. Among the pioneer studies in this area are those of Ryan \& Reinhardt (1988) and Ryan \& Frandsen (1991) with North American conifers. In Mexico, there are studies that use this approach with $P$. hartwegii (Rodríguez-Trejo et al. 2007), but they do not focus on relatively extensive prescribed burns and young trees. Moreover, recent studies in Mexico have been conducted in small, uniform plots ( 1 ha or less per experimental unit) and not in relatively extensive management-ignited prescribed burns with more variable conditions, such as those existing in our study area.

In this study we attempted to answer the following questions: (i) does low severity prescribed burn affect juvenile tree survival? (ii) Which are the factors better explaining juvenile tree mortality in a severe fire? (iii) How is the primary height growth of the surviving juvenile trees $(<5 \mathrm{~m})$ affected by fire?

The objectives of this work were to compare in a P. hartwegii stand: (a) the survival probability of trees of different heights, diameters and levels of fire damage; and (b) its leader shoot growth, after a relatively extensive management-ignited prescribed burn, after a wildfire and in an unburned control.

\section{Materials and methods}

\section{Study area}

The experiment was carried out in a $P$. hartwegii forest stand south of Mexico City, Mexico, on lands owned by the rural communities of San Miguel and Santo Tomás Ajusco, at an average altitude of 3250 $\mathrm{m}$ a.s.l. The main characteristics of the studied stand were: tree height ranging from 0.3 to $6.0 \mathrm{~m}$ (average: $3.1 \mathrm{~m}$ ) and diameter at breast height (dbh) 1 to $19 \mathrm{~cm}$ (average: $10 \mathrm{~cm}$ ), with an approximate stand age ranging from 2 to 25 years. These trees were growing under a low-density stand (50-80 trees ha ${ }^{-1}$ ) of adult trees (average height: $20 \mathrm{~m}$ ). To conduct this work a prescribed burn was carried out in a test area, and compared with a nearby wildfireaffected area as well as a non-affected area as control.

\section{Plots and treatments}

The experiment was conducted in three close plots, each with an approximate surface of 10 ha, at altitudes of 3215 to $3285 \mathrm{~m}$ a.s.l. $\left(19^{\circ} 09^{\prime} 55.55^{\prime \prime}\right.$ to $19^{\circ} 10^{\prime} 19.06^{\prime \prime} \mathrm{N}, 99^{\circ}$ $14^{\prime} 02.86^{\prime \prime}$ to $\left.99^{\circ} 14^{\prime} 43.54^{\prime \prime} \mathrm{W}\right)$. One of the plots had not been burned for at least 6 years and was taken as control. The second plot underwent a prescribed burn in March 2012, while the third plot was affected by a wildfire one week later (Fig. 1). The local topography is quite irregular, very rocky, with small flatlands but also frequent small hills ( 5 to $40 \mathrm{~m}$ in height) with occasional steep hillsides (slope up to $50 \%$ ).

The fuel complex was composed mostly of cured grasses. Needle litter was abundant in areas with high tree density, as well as light (1h timelag) or medium size (10 and $100 \mathrm{~h}$ timelag) woody litter (Weise et al. 2005). A fuel load of 3-12 $\mathrm{t} \mathrm{ha}^{-1}$ was estimated in different parts of the plots. Fuel loads were the same for the prescribed burn and the wildfire areas.

Both the low-intensity prescribed burn and the wildfire at the studied site occurred in March 2012 (Fig. 1), though the fire danger index showed marked differences during the two events. During the prescribed burn, relative humidity was $30-$ $50 \%$, temperature $15-20{ }^{\circ} \mathrm{C}$, and wind speed $0-15 \mathrm{~km} \mathrm{~h}^{-1}$. In this case, the dead fine fuel moisture was $6 \%$ (temperature: $20{ }^{\circ} \mathrm{C}$; relative humidity: 30\%; 12:00 a.m., S aspect and slope $<30 \%$ ) to $11 \%$ (temperature: $15^{\circ} \mathrm{C}$; relative humidity: 50\%; 8:00 a.m., $\mathrm{N}$ aspect and slope $>30 \%$ ), estimated with standard tables relating temperature and humidity to equilibrium moisture content. According to the Mexican System for the Prediction of Fire Danger (UJED 2018), the fire danger was medium to low the day the prescribed burn was applied (a hail storm occurred after mupping-up), while fire danger was high the day the wildfire occurred. The site is characterized by frequent changes in wind direction almost every day throughout the year. Because of both wind direction changes and irregular topography, a modified prescribed burn method was employed, a mix of the strip backing fire method (relative to the slope) and the

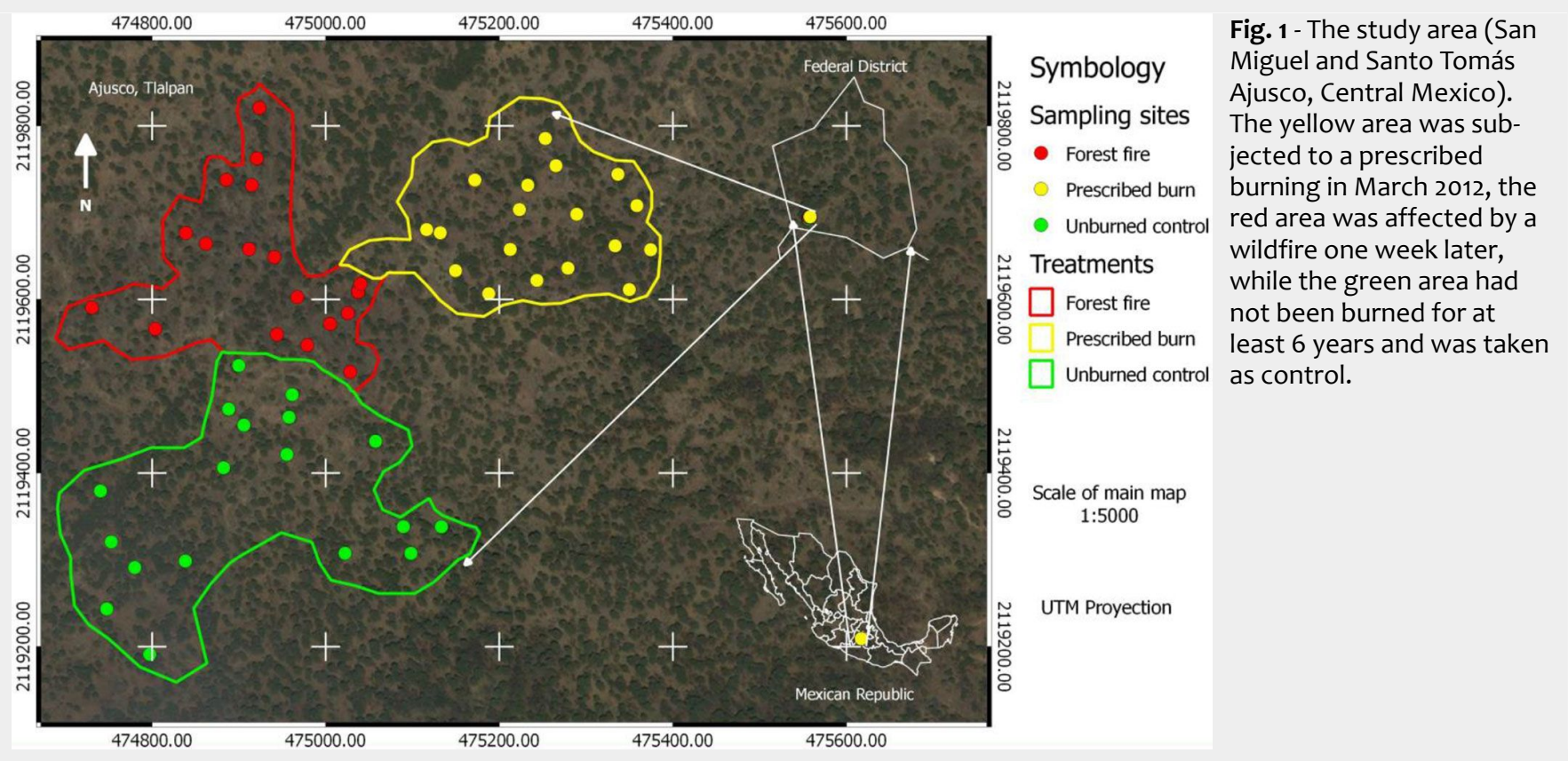


Tab. 1 - Tree and fire severity measurements for each plot. (h): tree height; (bd): basal diameter; (dbh): diameter at breast height; (Ic): live crown; (sc): scorched crown.

\begin{tabular}{|c|c|c|c|c|c|c|c|c|c|}
\hline Plot & Stat & $\begin{array}{l}\text { Stem char } \\
\text { height }(m)\end{array}$ & $\begin{array}{c}\mathrm{h} \\
(\mathrm{m})\end{array}$ & $\begin{array}{l}\text { Leader shoot } \\
\text { growth }(\mathrm{m})\end{array}$ & $\begin{array}{l}\mathrm{bd} \\
(\mathrm{cm})\end{array}$ & $\begin{array}{l}\mathrm{dbh} \\
(\mathrm{cm})\end{array}$ & $\begin{array}{l}\text { Tree-density } \\
\left(\mathrm{n} \mathrm{ha}^{-1}\right)\end{array}$ & $\begin{array}{l}\text { lc } \\
(\%)\end{array}$ & $\begin{array}{l}\mathrm{sc} \\
(\%)\end{array}$ \\
\hline \multirow[t]{3}{*}{ Control } & Min & - & 0.31 & 0.06 & 3.0 & 2.0 & 1000 & 10 & - \\
\hline & Max & - & 5.98 & 0.62 & 35.0 & 14.0 & 3400 & 95 & - \\
\hline & Avg & - & 2.32 & 0.26 & 9.0 & 5.0 & 2224 & 50 & - \\
\hline \multirow{3}{*}{$\begin{array}{l}\text { Prescribed } \\
\text { burn }\end{array}$} & Min & 0 & 1.10 & 0.04 & 3.0 & 1.0 & 900 & 0 & 0 \\
\hline & Max & 1.80 & 6.00 & 0.7 & 26.0 & 17.0 & 3800 & 100 & 100 \\
\hline & Avg & 0.48 & 2.66 & 0.25 & 8.0 & 5.0 & 2253 & 40.5 & 14.8 \\
\hline \multirow[t]{3}{*}{ Wildfire } & Min & 0.30 & 0.95 & 0.08 & 2.5 & 1.0 & 1600 & 0 & 0 \\
\hline & Max & 4.80 & 5.70 & 0.6 & 22.0 & 19.0 & 3900 & 80 & 100 \\
\hline & Avg & 1.67 & 2.53 & 0.25 & 8.0 & 5.0 & 2714 & 8.0 & 87.0 \\
\hline
\end{tabular}

Chevron method that was denominated the Ajusco method (Rodríguez-Trejo 2015). The fire started in parallel lines, beginning at the ridges of the small hills, thus it was a backing fire with respect to slope. Because of changes in the wind direction, the descendent fire sometimes advanced favored by the wind and sometimes against the wind, even perpendicular to wind direction. The prescribed burn was planned, directed and conducted by personnel of the Comisión Nacional Forestal (National Forestry Comission), the Comisión de Recursos Naturales (Natural Resources Commission of the Mexico City government), and the Universidad Autónoma Chapingo (Autonomous Chapingo University), as part of the Ajusco Research Project of the Universidad Autónoma Chapingo on fire ecology, integrated fire management and restoration of burned areas. In general, flame length was lower than $1 \mathrm{~m}$, and the rate of fire propagation was less than $1 \mathrm{~m} \mathrm{~min}^{-1}$ for these backing fires, though in some cases they reached 1.0-1.5 $\mathrm{m}$ and $3-5 \mathrm{~m} \mathrm{~min}^{-1}$ when the wind blew down the slope.

The wildfire occurred in March 2012, affecting an area of about 10 ha. It reached high intensity, with flame lengths $>5 \mathrm{~m}$ in some sectors (CONAFOR 2012b) causing high severity and high mortality among the juvenile trees. Crown scorch in trees smaller than $5 \mathrm{~m}$ was $100 \%$, and stem char height was up to $5 \mathrm{~m}$ on some adult trees.

By September 2012, six months after the prescribed burn, a randomized sampling in each plot was conducted with squareshaped sampling units of $100 \mathrm{~m}^{2}, 18 \mathrm{per}$ treatment, for a total of 54 sampling units and a sampling intensity of $1.8 \%$. A total of 1148 young trees were sampled.

For each tree in all plots we recorded the tree vitality (a tree was considered alive when showing any amount of green foliage), diameter at breast height $(1.3 \mathrm{~m})$, basal diameter at the root collar, tree height, length of the leader shoot, stem char height, percent of live crown, percentage of scorched crown (lethal for the buds). For each sampling unit, tree density of live and dead trees was also calculated.

\section{Statistical analysis}

Logistic regression (Hosmer \& Lemeshow 2000) was performed to obtain the probability of juvenile tree mortality ( $P$ - eqn. 1$)$ :

$$
P=\frac{1}{1+e^{-\left(\alpha+\beta_{1} X_{1}+\beta_{2} X_{2}+\beta_{3} X_{3}\right)}}
$$

where $e$ is the Euler number, $\alpha$ the intercept, and $\beta$ the constants associated with the independent variables $X$.

To consider a model significant, all variable included must show $\mathrm{p}<0.05$, an odds confidence interval lower or higher than 1 , and a high concordance ratio (number of concordant pairs divided by the total number of pairs). Models including each individual variable and all the combinations of individual variables were tested, and the more significant model was finally chosen.

A linear multiple regression model was used to find the variables mostly related to the leader shoot growth (Ls - eqn. 2):

$$
L s=\beta_{0}+\beta_{1} X_{1}+\cdots+\beta_{n} X_{n}
$$

where $\beta_{0, \ldots, n}$ are constants and $X_{1, \ldots, n}$ are the independent variables.

The statistical analysis for the logistic model was carried out using the PROC LOGISTIC of the SAS ${ }^{\circledast}$ ver. 9.0 package (SAS Institute 2002). The regression model was obtained using the procedure PROC GLM.

\section{Results}

Tree characteristics and fire severity

The sampled trees were young, with an average height of 2.66 and $2.53 \mathrm{~m}$ in the areas treated with prescribed fire or those af-

Tab. 2 - Significance of the parameters for the logistic regression model to predict mortality probability of Pinus hartwegii in the prescribed burn and wildfire treatments.

\begin{tabular}{lcrrrr}
\hline Parameter & DF & Estimation & $\begin{array}{c}\text { Standard } \\
\text { error }\end{array}$ & \multicolumn{1}{c}{$\chi^{2}$} & \multicolumn{1}{c}{ P } \\
\hline Intercept & 1 & 1.1025 & 0.3025 & 13.2881 & 0.0003 \\
Stem char height & 1 & 4.4095 & 0.3576 & 152.0642 & $<0.0001$ \\
Height & 1 & -0.5213 & 0.2592 & 4.0445 & 0.0443 \\
Diameter at breast height & 1 & -88.4305 & 10.9090 & 65.7100 & $<0.0001$ \\
\hline
\end{tabular}

fected by wildfire, respectively. In both areas, the mean $\mathrm{dbh}$ was $5 \mathrm{~cm}$. Severity of the prescribed fire was low and satisfactory, with a mean stem char height of 0.48 $\mathrm{m}$ and an average crown scorch of $14.8 \%$, while the wildfire resulted in high severity, reaching $1.67 \mathrm{~m}$ for average stem char height and $87 \%$ for crown scorch (Tab. 1).

\section{Probability of mortality}

No dead trees were recorded in the control plot, while in the prescribed burn plot mortality was $6 \%$, mostly affecting trees with height $<1 \mathrm{~m}$. In the wildfire plot, mortality reached $66.9 \%$ and most of the dead trees were $\leq 3 \mathrm{~m}$ tall. mortality obtained from both the prescribed burn and the wildfire plots (eqn. 3) was significant $\left(\chi^{2}=552.1133, p<0.0001\right)$. The significance of each of the explanatory variables is shown in Tab. 2. Concordance of the model reached $94.5 \%$ (eqn. 3 ):

$$
P=\frac{1}{1+\exp ^{-\left(1.1025+4.4095 X_{1}-0.5213 X_{2}-88.4305 X_{3}\right)}}
$$

where $P$ is the probability of mortality for juvenile $P$. hartwegii, $X_{1}$ is the stem char height, $X_{2}$ is the tree height, $X_{3}$ is the diameter at breast height.

The confidence intervals for the variables in the model did not include the value 1 in a higher probability of mortality for the wildfire area. $P$ maximizes when the $\mathrm{dbh}$ is small and stem char height is high, which is associated with large crown damage (Fig. 2).

Based on the model obtained, a tree $1.3 \mathrm{~m}$
The regression model for probability of any case. As expected, the model predicts 

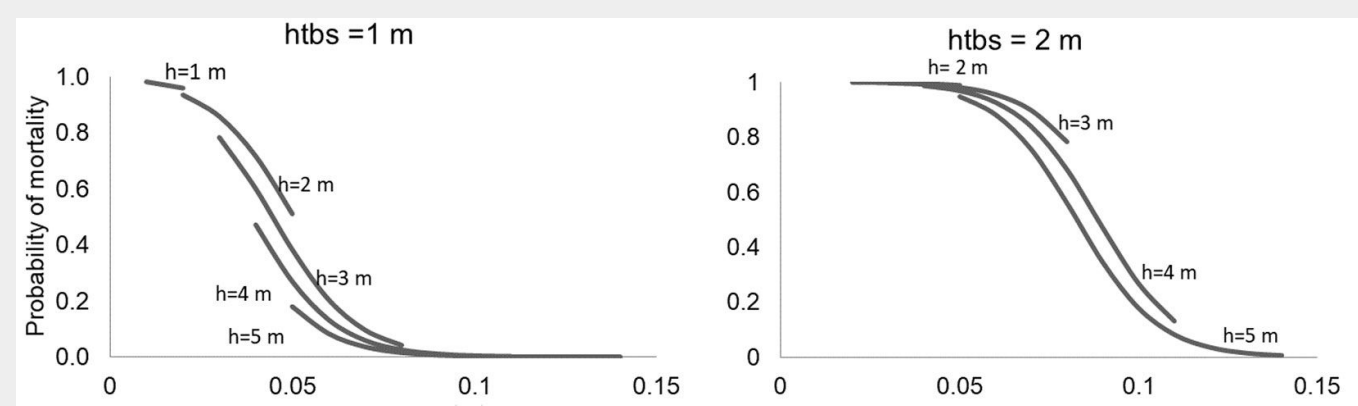

Fig. 2 - Probability of mortality as a function of the explanatory variables. (htbs): stem char heigth; (h): tree height.
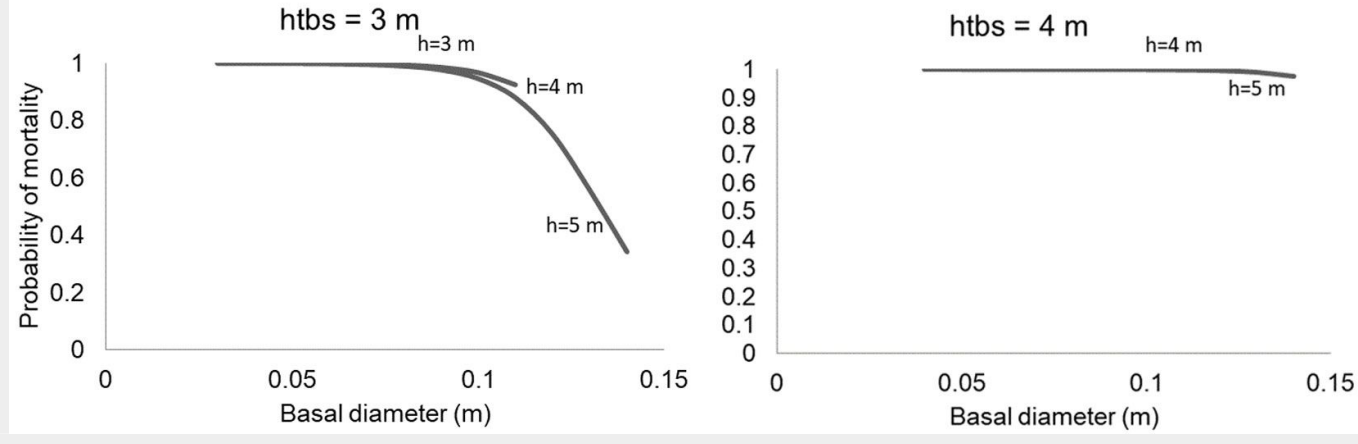

tall, with a stem char height of $1.2 \mathrm{~m}$ and a basal diameter of $4 \mathrm{~cm}$ has an $89.8 \%$ probability of mortality, while another tree $3.8 \mathrm{~m}$ tall, with a stem char height of $0.6 \mathrm{~m}$ and a basal diameter of $15 \mathrm{~cm}$, has a $0.0001 \%$ probability of mortality.

\section{Tree leader shoot growth}

The variables most closely associated where $L s$ is the leader shoot growth $(\mathrm{m}), X_{1}$ with leader shoot growth in the linear the stem char height $(\mathrm{m})$, and $X_{2}$ the tree model were stem char height $(p<0.0001)$ height $(m)$.

Tab. 3 - Significance of the parameters for the multiple regression model to predict the leader shoot growth of juvenile Pinus hartwegii.

\begin{tabular}{lcccc}
\hline Parameter & Estimation & Standard Error & $t$ & $P$ \\
\hline Intercept & 0.07163 & 0.00643 & 11.13 & $<0.0001$ \\
Stem char height & -0.10365 & 0.00479 & -21.65 & $<0.0001$ \\
Tree height & 0.07740 & 0.00296 & 26.12 & $<0.0001$ \\
\hline
\end{tabular}

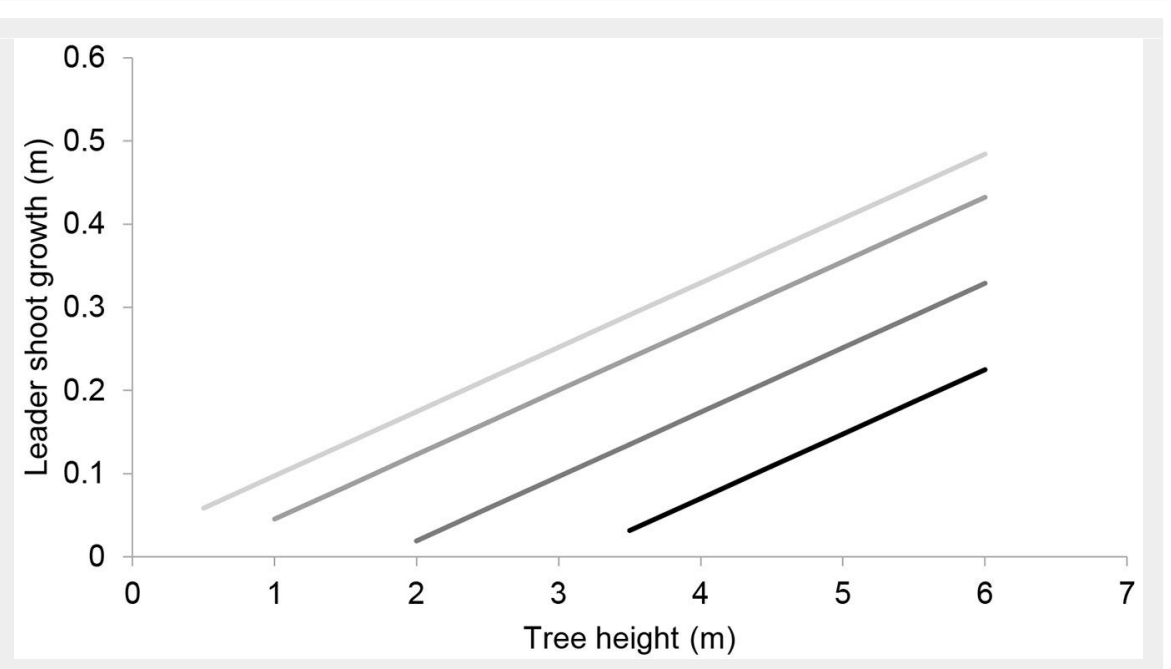

Fig. 3 - Relationship between total tree height and leader shoot growth at different stem char heights, wildfire and prescribed burn treatments. Progressively darker lines (left to right) represent stem char heights of $0.5,1,2$ and $3 \mathrm{~m}$.
According to this model, a $3.10 \mathrm{~m}$ tall tree with a stem char height of $0.8 \mathrm{~m}$ had a leader shoot growth of $0.23 \mathrm{~m}$, and the same tree with a stem char height of $2.0 \mathrm{~m}$ would have an increment of only $0.10 \mathrm{~m}$.

\section{4) Discussion}

In a low-intensity prescribed burn carried out in small ( 1 ha) and uniform plots of $P$. hartwegii under less variable wind and topographic conditions, Rodríguez-Trejo et al. (2007) found a mortality of $4.4 \%$ one year after the treatment application. In this study, a similar low mortality and a high juvenile tree survival was observed, despite the irregular topography and the changes in wind direction during the experiment. $A$ small increase in mortality is expected one or two years after wildfire, while such increase is expected to be negligible for the prescribed burn. For the same experimental area, Vera-Vilchis \& Rodríguez-Trejo et al. (2007) found no mortality increase two year after the prescribed burns. However, in the case of a high intensity prescribed burn in May (emulating a wildfire), mortality was $52 \%$ one year later and rose to $67.3 \%$ two years after the treatment.

Older trees have thicker bark that isolates the vascular cambium from lethal temperatures and higher crowns less subjected to damage from fire (Ryan \& Frandsen 1991, Miller 2000); therefore, the probability of mortality tends to be lower. However, with higher damage, i.e., higher stem char height or higher crown scorch, more photosynthetic tissue is affected in the crown, and the vascular tissue receives more damage, resulting in higher mortality (Ryan \& Reinhardt 1988, Woolley et al. 2012, RoblesGutiérrez et al. 2015). Mchugh \& Kolb (2003) reported that mortality of Pinus ponderosa is influenced by the interaction between crown damage and severity of trunk damage, as well as by differences in 
fire resistance among trees.

Several studies demonstrated that when fire causes low crown scorch, primary and secondary growth during the following growth season is higher than in unburned controls, unless a severe drought occurs. This has been found for species such as $P$. palustris Mill. (Grelen 1983), P. lambertiana Dougl. (Mutch \& Parsons 1998), and P. hartwegii (González-Rosales \& RodríguezTrejo 2004). This response is related to the ashes produced by fire which are rich in cations and to the higher solar radiation on burned sites, as well as to the pruning of lower and older branches that have less photosyntetically efficient needles than younger and higher branches.

The wildfire occurred in the study area was severe because an important part of the forest fuels was represented by dead needles. Indeed, the burning of such fuel causes lethal temperatures for the surface roots, greater damage and mortality, as demonstrated for P. palustris (Brockway \& Outcalt 1998) and P. hartwegii (RodríguezTrejo et al. 2007). Vera-Vilchis \& RodríguezTrejo (2007), found that after low intensity prescribed burns carried out in May on high density juvenile stands, tree leader shoots had a growth of $8.2 \mathrm{~cm} \mathrm{~m}^{-1} \mathrm{y}^{-1}$, i.e., $32 \%$ higher than the unburned control $(6.2$ $\left.\mathrm{cm} \mathrm{m}^{-1} \mathrm{y}^{-1}\right)$. In the same study, the probability of mortality was higher at high density than at low density, but it apparently enlarged the growing space and favored height growth of surviving trees.

In this study stem char height and tree height, which were associated with tree leader shoot growth in the linear model, also affect tree survival. The higher the stem char height, the smaller the tree leader shoot growth, as damages on the trunk usually lead to a reduction of sap and water flux to the crown. Other types of damage have been associated with lower primary growth. For instance, Chambers et al. (1986) found a reduction in height growth of $0.73 \mathrm{~m}$ in conifer trees with a crown scorch of 30 to $40 \%$; the reduction reached $1.71 \mathrm{~m}$ when the crown scorch was 85 to $99 \%$, in a 4.5 -year period.

Tree leader shoot growth was positively influenced by tree height because, in general, taller trees have thicker trunk and thicker bark, and leaf tissue may be far from fire lethal temperatures. However, even higher fire resistance in older trees becomes useless when the forest accumulates more fuels due to fire exclusion, and then intentional or accidental fires are more intense and severe. Thus, older trees have a higher probability of mortality than younger ones, as found for $P$. ponderosa in Montana (Ryan \& Frandsen 1991), Calocedrus decurrens (Torr.) Florin, Abies concolor (Gord. \& Glend.) Lindl. ex Hildebr., P. lambertiana Douglas, $P$. jeffreyi Balf., and $P$. ponderosa in California (Hood et al. 2010). Conversely, Pollet \& Omi (2002), in P. ponderosa Laws forests, found that clearing and prescribed burning significantly reduce crown scorch, so that severity of future fires was lowered.

\section{Conclusions}

The main concern of the application of extensive prescribed burning is its effect on young trees. This study provides evidence of the advantages of low intensity and low severity prescribed burning carried out in March, since it does not cause significant mortality and can favor the growth of juveniles of the studied tree species. The smaller the tree diameter the higher the probability of mortality, particularly with high severity wildfires in dense stands. If the stem char height is high, the probability of mortality will also increase. Fire damage on trees, as evidenced by stem char height, is inversely related to shoot leader growth. However, old stands may have high accumulations of forest fuels, causing high mortality in old trees in the case of wildfire occurrence.

In pursuing the objectives of prescribed burning in the studied ecosystem, it is mandatory to prevent significant mortality of trees, particularly the young ones. We demonstrated that this can be achieved with extensive prescribed burns, using the Ajusco method and following the prescription. If other objectives, such as resprouting from grasses to feed cattle and sheep (main cause of wildfires in Mexico), are fitted into this type of prescribed burns, together with the prevention of wildfires (through fuel reduction), an integrated fire management can be achieved. This is a useful fire management option for Mexico to be combined with traditional fire prevention measures and the firefighting.

\section{Acknowledgements}

RHC co-conceived the study, carried out field measurements, helped with statistical analysis and helped to draft the manuscript and figures. DART co-conceived the study, participated in the prescribed burn, helped with field measurements, helped with the statistical analysis and to draft the manuscript. ACR directed the prescribed burn.

We thank José Luis Gallardo, César Robles, and the firefighter personnel of Conafor Ciudad de México for their invaluable help in the field. We thank Kevin C. Ryan for his kind review and suggestions to improve this paper, and Diane Fumiko for her help editing the English translation of this work. Funding was provided by the Universidad Autónoma Chapingo and the logistic and field help was provided by the Comisión Nacional Forestal Ciudad de México and the Comisión de Recursos Naturales, Gobierno de la Ciudad de México.

\section{References}

Agee JK (1993). Fire ecology of Pacific Northwest forests. Island Press, Washington, DC, USA, pp. 493.

Brockway DG, Outcalt KW (1998). Gap-phase regeneration in longleaf pine wire grass ecosystems. Forest Ecology and Management 106:
125-139. - doi: 10.1016/S0378-1127(97)00308-3 Chambers JL, Dougherty PM, Hennessey TC (1986). Fire: Its effects on growth and physiological processes in conifer forests. In: "Stress Physiology and Forest Productivity" (Hennessey TC, Dougherty PM, Kossuths V, Johnson JD eds). Martinus Nijhoff Publications, Boston, MA, USA, pp. 177-189.

CONAFOR (2012a). Reporte de incendios forestales [Forest fires report]. Comisión Nacional Forestal - CONAFOR, México, pp. 18. [in Spanish] [online] URL: https://snigf.cnf.gob.mx/wpcontent/uploads/Incendios/Informes\%20anuale s/Informe-final-de-Incendios-Forestales-2012. pdf

CONAFOR (2012b). Programas y acciones de reforestación, conservación y restauración de suelos, incendios forestales y sanidad forestal [Programs and actions on reforestation, conservation and restoration of soils, forest fires and forest health]. Comisión Nacional Forestal CONAFOR, México, pp. 172. [in Spanish]

Espinoza-Martínez A, Rodríguez-Trejo DA, Zamudio-Sánchez JF (2008). Sinecología del sotobosque de Pinus hartwegii dos y tres años después de quemas prescritas [Synecology of the understory of Pinus hartwegii two and three years after prescribed burns]. Agrociencia 42: 717-730. [in Spanish]

Farjon AJ, Pérez De La Rosa A, Styles BT (1997). A field guide to the pines of Mexico and Central America. Royal Botanic Gardens, Kew, UK, pp. 147.

Fernandes PM, Vega JS, Jiménez E, Rigolot E (2008). Fire resistance of European pines. Forest Ecology and Management 256: 246-255. doi: 10.1016/j.foreco.2008.04.032

González-Rosales A, Rodríguez-Trejo DA (2004). Efecto del chamuscado de copa en el crecimiento en diámetro de Pinus hartwegii Lindl. [Effect of crown scorch on the diameter growth of Pinus hartwegii Lind.]. Agrociencia 38: 537-544. [in Spanish]

Grelen HE (1983). May burning favor survival and early growth of longleaf pine seedlings? Southern Journal of Applied Forestry 7: 16-20.

Hood SM, Smith SL, Cluck DR (2010). Predicting mortality of five California conifers following wildfire. Forest Ecology and Management 260: 750-762. - doi: 10.1016/j.foreco.2010.05.033

Hosmer DW, Lemeshow S (2000). Applied logistic regression. Wiley, New York, USA, pp. 392. Islas-Madrid GE, Rodríguez-Trejo DA, Martínez HPA (2013). Diversidad del sotobosque y radiación solar en un bosque de Pinus hartwegii con quema prescrita [Understory diversity and solar radiation in a Pinus hartwegii forest after a prescribed burn]. Revista Mexicana de Ciencias Forestales 4: 25-40. [in Spanish] - doi: 10.29298/rmcf.v4i15.446

Keeley JE (2012). Ecology and evolution of pine life histories. Annals of Forest Science 69: 445453. - doi: 10.1007/s13595-012-0201-8

Martínez-Hernández HC, Rodríguez-Trejo DA (2008). Species diversity after prescribed burns at different intensities and seasons in a high altitude Pinus hartwegii forest. Interciencia 33: 337-344.

Mchugh CW, Kolb TE (2003). Ponderosa pine mortality following fire in northern Arizona. International Journal of Wildland Fire 12: 7-22. 
doi: 10.1071/WF02054

Miller M (2000). Fire autecology. In: "Wildland Fire in Ecosystems. Effects of Fire on Flora" (Brown JK, Smith JK eds). Technical Report RMRS-GTR-42 vol. 2, USDA Forest Service, Rocky Mountain Research Station, Ogden, UT, USA, pp. 9-34.

Mutch LS, Parsons DJ (1998). Mixed conifer forest mortality and establishment before and after prescribed burning in Sequoia National Park, California. Forest Science 44: 341-355.

Myers RL (2005). Convivir con el fuego. Manteniendo los ecosistemas y los medios de subsistencia mediante el Manejo Integral del Fuego [Living with fire. Sustaining ecosystems and livelihoods through Integrated Fire Management]. The Nature Conservancy, Tallahassee, FL, USA. pp. 28. [in Spanish]

Perry JP (1991). The pines of Mexico and Central America. Timber Press, Portland, OR, USA, pp. 231.

Pollet J, Omi PN (2002). Effect of thinning and prescribed burning on crown fire severity in ponderosa pine forests. International Journal of Wildland Fire 11: 1-10. - doi: 10.1071/WF01045 Robles-Gutiérrez CA, Velázquez-Martínez A, Rodríguez-Trejo DA, Reyes-Hernández VJ, Etchevers-Barra JE (2015). Probability of mortality by fire damage of young Pinus hartwegii Lindl. trees in the Izta-Popo National Park. Revista Chapingo Serie Ciencias Forestales y del Ambiente 22: 165-178.

Rodríguez-Trejo DA (2000). Educación e incendios forestales [Education and forest fires]. Mundi Prensa, México, pp. 201. [in Spanish] Rodríguez-Trejo DA, Fulé PZ (2003). Fire ecology of Mexican pines and a fire management proposal. International Journal Wildland Fire 12: 2337. - doi: 10.1071/WF02040

Rodríguez-Trejo DA, Castro-Solis UB, ZepedaBautista M, Carr RJ (2007). First year survival of Pinus hartwegii following prescribed burns at different intensities and different seasons in central Mexico. International Journal of Wildland Fire 16: 54-62. - doi: 10.1071/WF05061

Rodríguez-Trejo DA (2014). Incendios de vegetación. Su ecología, manejo e historia [Forest fires. Ecology, management and history]. Vol. 1. Ed. C.P., UACH, Semarnat, Conafor, PNIP, Conanp, México, pp. 889.Rodríguez-Trejo DA (2000). Educación e incendios forestales [Education and forest fires]. Mundi Prensa, México, pp. 201. [in Spanish]

Rodríguez-Trejo DA (2015). Incendios de vegetación. Su ecología, manejo e historia [Forest fires. Ecology, management and history]. Vol. 2. Ed. C.P., UACH, Semarnat, Conafor, PNIP, Conanp, FMCN, Gobierno do Tabasco, México. pp. 812. [in Spanish]

Ryan KC, Frandsen WH (1991). Basal injury from smoldering fires in mature Pinus ponderosa Laws. International Journal of Wildland Fire 1: 107-118. - doi: 10.1071/WF9910107

Ryan KC, Reinhardt ED (1988). Predicting postfire mortality of seven western conifers in wildfires. Canadian Journal of Forest Research 3: 373-378.

SAS Institute (2002). Statistical analysis system. SAS Institute, Raleigh, NC, USA.

Scott AD, Bowman DMJS, Bond WJ, Pyne SJ, Alexander ME (2014). Fire on earth. An introduction. Wiley-Blackwell, Singapore, pp. 413.
SEMARNAP/UACH (1999). Atlas forestal de México [Mexico's forestry atlas]. SEMARNAP - Secretaría de Medio Ambiente, Recursos Naturales y Pesca, UACH - Universidad Autónoma Chapingo, México, pp. 103. [in Spanish]

UJED (2018). Sistema de predicción de peligro de incendios forestales de México. Evolución semanal de peligro de incendio e incendios combatidos [Mexico's Forest Fires Prediction System. Weekly evolution of forest fire danger and fighted forest fires]. Universidad Juárez del Estado de Durango, Durango, México. [in Spanish] [online] URL: http://forestales.ujed.mx/in cendios/inicio/historicos animaciones.php Vera-Vilchis V, Rodríguez-Trejo DA (2007). Supervivencia e incremento en altura de Pinus hartwegii a dos años de quemas prescritas e incendios experimentales [Survival and height increment of Pinus hartwegii two years after prescribed burns and experimental forest fires]. Agrociencia 41: 219-230. [in Spanish]

Weise DR, Fujioka FM, Nelson MRJ (2005). A comparison of three models of $1 \mathrm{~h}$ time-lag fuel moisture in Hawaii. Agricultural and Forest Meteorology 133: 28-39. - doi: 10.1016/j.agrformet. 2005.03.012

Whelan RJ (1997). The ecology of fire. Cambridge University Press, Cambridge, UK, pp. 346.

Woolley T, Shaw DC, Ganio LM, Fitzgerald S (2012). A review of logistic regression models used to predict post-fire tree mortality of western North American conifers. International Journal of Wildland Fire 21: 1-35. - doi: 10.1071/ WFo9039 